\title{
PERAN PENDIDIKAN DALAM MENCIPTAKAN SUMBER DAYA MANUSIA BERKUALITAS di PROVINSI SULAWESI UTARA
}

\author{
Jeane Mantiri \\ Prodi Ilmu Administrasi Negara FIS Unima \\ jeanelitha@unima.ac.id
}

\begin{abstract}
ABSTRAK
Secara mikro, sumber daya manusia (SDM) memegang peran penting untuk kemajuan suatu lembaga atau organisasi dan secara makro SDM menentukan kemajuan suatu bangsa. Sesuai dengan Undang-undang pendidikan berperan menciptakan SDM berkualitas. Kenyataan generasi muda berbondong-bondong mengikuti pendidikan diberbagai jenjang dengan tujuan mau meningkatkan kualitas dirinya. Namun dengan berkembangnya angka partisipasi sekolah, penganguran berdasipun ikut berkembang. Banyak para sarjana tidak memiliki pekerjaan. Melihat pentingnya peran SDM, perlu dilakukan upaya perbaikan dan peningkatan SDM yang ada serta upaya pembentukan SDM yang berkualitas. Pada hakekatnya pendidikan adalah "Si Tou Timou Tumou Tou" yang artinya manusia hidup untuk menghidupi sesama manusia. Dalam dunia pendidikan guru sebagai SDM lembaga pendidikan bertugas untuk menciptakan sumber daya manusia baru yang berkualitas. Selanjutnya manajemen SDM dibutuhkan dalam pendidikan baik pada tingkat makro dan ditingkat mikro sehingga tujuan pendidikan tercapai atau pendidikan mampu menciptakan atau mengembangkan potensi peserta didik agar menjadi manusia yang beriman, bertaqwa kepada Tuhan Yang Maha Esa, memiliki ahklak mulia, sehat berilmu, kreatif, cakap, mandiri dan demokratis serta bertanggung jawab dengan kata lain pendidikan mampu menciptakan sumber daya manusia yang berkualitas dan siap pakai.
\end{abstract}

\section{Keywords : Peran Pendidikan, Sumber Daya Manusia, Pendidikan Berkualitas}

\section{PENDAHULUAN}

Kemajuan suatu bangsa ditentukan oleh kualitas sumber daya manusia yang ada. Perkembangan zaman yang begitu maju sekarang ini tidak berarti sama sekali jika tidak ditunjang oleh sumber daya manusia yang berkualitas. Intinya sumber daya manusia merupakan unsur yang penting dalam memajukan suatu bangsa.

Demikian halnya dalam dunia pendidikan tinggi. Komponen-komponen penilaian untuk pemeringkatan lembaga lembaga pendidikan tinggi yang dilakukan oleh kemenristekdikti adalah Sumber daya manusia, kemahasiswaan, akreditasi, penelitian dan publikasi. Sumber daya manusia merupakan salah satu komponen yang memiliki point terbesar dalam pemeringkatan tersebut. Hal ini menunjukan secara mikro, sumber daya manusia memegang peran penting untuk kemajuan suatu lembaga atau organisasi dan secara makro sumber daya manusia menentukan kemajuan suatu bangsa.

Melihat pentingnya peran sumber daya manusia, perlu dilakukan upaya perbaikan dan peningkatan sumber daya manusia yang ada serta upaya pembentukan sumber daya manusia yang berkualitas.

Pendidikan merupakan salah satu unsur yang berperan menciptakan sumber daya manusia berkualitas, hal ini sesuai dengan amanat dari pasal 3 Undang-undang nomor 20 tahun 2003 tentang system pendidikan nasional yang menyatakan bahwa tujuan pendidikan nasional adalah menciptakan atau 
mengembangkan potensi peserta didik agar menjadi manusia yang beriman, bertaqwa kepada Tuhan Yang Maha Esa, memiliki ahklak mulia, sehat, berilmu, kreatif, cakap, mandiri dan demokratis serta bertanggung jawab.

Kenyataan yang terlihat sekarang adalah generasi muda berbondong-bondong mengikuti pendidikan diberbagai jenjang dengan tujuan mau meningkatkan kualitas dirinya sehingga menyandang predikat sumber daya manusia yang berkualitas dan dapat menjadi bagian dari kemajuan bangsa. Hal ini dapat dilihat dari data yang dikeluarkan oleh BPS Sulut pada tabel 1 yakni tabel angka partisipasi kasar. Namun seiring dengan berkembangnya angka partisipasi sekolah, penganguran berdasipun ikut berkembang. Banyak para sarjana tidak memiliki pekerjaan.

Tabel 1.1. Angka Partisipasi Kasar Sulut

\begin{tabular}{|l|r|r|r|}
\multirow{2}{*}{\multicolumn{1}{|c}{ Kabupaten/Kota }} & \multicolumn{3}{|c|}{$\begin{array}{c}\text { Angka Partisipasi Kasar(APK) } \\
\text { (Persen) }\end{array}$} \\
\cline { 2 - 4 } & \multicolumn{1}{|c|}{ SD } & \multicolumn{1}{c|}{ SMP } & \multicolumn{1}{c|}{ SMA } \\
\hline Bolaang Mongondow & 109.87 & 95.13 & 66.57 \\
\hline Minahasa & 116.78 & 82.54 & 110.2 \\
\hline Kepulauan Sangihe & 104.45 & 96.88 & 75.79 \\
\hline Kepulauan Talaud & 106.4 & 86.73 & 88.98 \\
\hline Minahasa Selatan & 113.47 & 83.38 & 99.24 \\
\hline Minahasa Utara & 118.03 & 91.92 & 82.92 \\
\hline $\begin{array}{l}\text { Bolaang Mongondow } \\
\text { Utara }\end{array}$ & 108.73 & 85.15 & 99.85 \\
\hline Kepulauan Sitaro & 105.52 & 90.29 & 79.22 \\
\hline Minahasa Tenggara & 113.85 & 80.19 & 95.44 \\
\hline $\begin{array}{l}\text { Bolaang Mongondow } \\
\text { Selatan }\end{array}$ & 114.55 & 79.53 & 81.82 \\
\hline $\begin{array}{l}\text { Bolaang Mongondow } \\
\text { Timur }\end{array}$ & 111.47 & 91.36 & 87.31 \\
\hline Kota Manado & 111.41 & 91.15 & 86.73 \\
\hline Bitung & 112.14 & 93.39 & 77.69 \\
\hline Kota Tomohon & 102.02 & 102.61 & 97.57 \\
\hline Kota Kotamobagu & 102.53 & 127.05 & 68.33 \\
\hline Sulawesi Utara & 111.23 & 91.06 & 86.3 \\
\hline
\end{tabular}

Sumber: http://sulut.bps.go.id/

Dari data badan pusat statistik angka penganguran terbuka Indonesia pada tahun 2015 bulan febuari sebesar $5,81 \%$ dan pada tahun 2016 bulan febuari tercatan 5,5\%, walau terlihat angka penganguran terbuka menurun tapi jika dilihat dalam jenjang pendidikan angka tingkat penganguran terbuka jenjang pendidikan lulusan sarjana justru mengalami peningkatan yang signifikan dari 5,34 \% pada febuari 2015 menjadi 6,22 \% pada febuari 2016. Selanjutnya menurut data pusat statistik Sulut ditahun 2015 penganguran terbuka berjumlah 99.240 jiwa, dan untuk data per kabupaten kota dapat dilihat pada tabel 2. Yaitu tabel kegiatan utama menurut kabupaten kota. Angka penganguran terbuka di Sulut 
meningkat dari tahun 2014 berjumlah 79.996 jiwa menjadi 99.240 jiwa. Data BPS Sulut dari tahun 2002 sampai 2015 menjukan angka pekerja meningkat namun pengangguran terbuka juga ikut meningkat dari tahun 2012 sampai tahun 2015 dan pengangguran terbuka menurut pendidikan lulusan sarjana $6,2 \%$. Penganguran dengan lulusan sarjana terjadi karena sebagian besar lulusan sarjana memiliki keinginan kerja formal atau pegawai negeri sipil namun untuk penerimaan PNS beberapa tahun terakhir tidak dilaksanakan atau dikurangi.

Hal ini merupakan kenyataan bahwa pendidikan yang digelar sampai saat ini belum mampu menciptakan manusia yang kreatif, cakap, mandiri.

Tabel. 2. Data Kegiatan Utama Menurut Kabupaten dan Kota

\begin{tabular}{|c|c|c|c|c|}
\hline \multirow{2}{*}{ Kabupaten/Kota } & \multicolumn{4}{|c|}{$\begin{array}{c}2015 \\
\text { Kegiatan Utama Menurut Kabupaten/Kota } \\
\text { (Jiwa) }\end{array}$} \\
\hline & $\begin{array}{c}\text { Angkatan } \\
\text { Kerja }\end{array}$ & $\begin{array}{l}\text { Bukan } \\
\text { Angkatan } \\
\text { Keria }\end{array}$ & Bekerja & $\begin{array}{c}\text { Pengangguran } \\
\text { Terbuka }\end{array}$ \\
\hline Bolaang Mongondow & 105166 & 166680 & 99102 & 6064 \\
\hline Minahasa & 150882 & 253270 & 136369 & 14513 \\
\hline Kepulauan Sangihe & 63487 & 99755 & 58983 & 4504 \\
\hline Kepulauan Talaud & 46860 & 65051 & 45915 & 945 \\
\hline Minahasa Selatan & 96420 & 152217 & 89811 & 6609 \\
\hline Minahasa Utara & 81587 & 146692 & 73360 & 8227 \\
\hline $\begin{array}{l}\text { Bolaang Mongondow } \\
\text { Utara }\end{array}$ & 30855 & 53448 & 29945 & 910 \\
\hline Kepulauan Sitaro & 28572 & 50388 & 26798 & 1774 \\
\hline Minahasa Tenggara & 47593 & 75050 & 45472 & 2121 \\
\hline $\begin{array}{l}\text { Bolaang Mongondow } \\
\text { Selatan }\end{array}$ & 24580 & 41985 & 22913 & 1667 \\
\hline $\begin{array}{l}\text { Bolaang Mongondow } \\
\text { Timur }\end{array}$ & 33850 & 50042 & 31415 & 2435 \\
\hline Kota Manado & 193134 & 324428 & 165561 & 27573 \\
\hline Bitung & 91390 & 149160 & 80542 & 10848 \\
\hline Kota Tomohon & 49516 & 77159 & 44098 & 5418 \\
\hline Kota Kotamobagu & 55380 & 88380 & 49748 & 5632 \\
\hline Sulawesi Utara & 1099272 & 1793705 & 1000032 & 99240 \\
\hline
\end{tabular}

Sumber: http://sulut.bps.go.id/

Seperti yang disampaikan Kepala Dinas Tenaga Kerja dan Transmigrasi (Disnakertrans) Sulut, Marsel Sendoh bahwa meningkatnya angka penganguran dengan lulusan sarjana karena "mereka kemungkinan masih menunggu penerimaan kerja, atau memilih menganggur dari pada bekerja tidak sesuai dengan kompetensinya"

Oleh sebab itu perlu dilakukan pembenahan dalam system pendidikan sehingga benar-benar pendidikan memiliki peran menciptakan sumber daya manusia yang kreatif dan cakap serta mandiri disegala bidang dapat tercapai sesuai dengan tujuan pendidikan nasional yang tertuang dalam Undang-Undang nomor 20 tahun 2003, dan membantu pemerintah dalam hal pembangunan manusia atau dalam usaha penekanan angka pengangguran serta angka kemiskinan dengan cara menciptakan lapangan pekerjaan sendiri.

Berdasarkan uraian fenomena diatas, penulis menjadi tertarik untuk mengkaji lebih 
dalam tentang peran pendidikan dalam menciptakan sumber daya manusia berkualitas.

Tabel 3. Data Kegiatan Utama

\begin{tabular}{|l|c|c|c|c|c|c|c|c|c|c|c|c|c|c|}
\hline \multirow{2}{*}{ Kegiatan Utama } & \multicolumn{10}{|c|}{ Kegiatan Utama (Jiwa) } \\
\cline { 2 - 15 } & 2002 & 2003 & 2004 & 2005 & 2006 & 2007 & 2008 & 2009 & 2011 & 2012 & 2013 & 2014 & 2015 \\
\hline Angkatan Kerja & 900105 & 900105 & 980444 & 998398 & 970416 & 1036499 & 1020952 & 1051130 & 1036574 & 1084203 & 1038128 & 1014600 & 1060752 & 1099200 \\
\hline Bukan Angkatan Kerja & 1478500 & 1478500 & 1598814 & 1601686 & 1639282 & 1672655 & 1669313 & 1694125 & 1637366 & 1659814 & 1676231 & 1697919 & 1768162 & 1793600 \\
\hline Bekerja & 797923 & 797923 & 873436 & 854646 & 828550 & 908503 & 912198 & 940173 & 936939 & 990720 & 957292 & 946852 & 980756 & 1000000 \\
\hline Pengangguran Terbuka & 102182 & 102182 & 107008 & 143752 & 141866 & 127996 & 108754 & 110957 & 99635 & 93483 & 80836 & 67748 & 79996 & 99200 \\
\hline
\end{tabular}

Sumber: http://sulut.bps.go.id/

\section{PEMBAHASAN}

Dalam undang-undang Sistem Pendidikan Nasional nomor 20 Tahun 2003 pasal 1 ayat 1 dijelaskan bahwa pendidikan merupakan usaha sadar dan terencana dalam usaha mewujudkan proses pembelajaran dan suasana belajar agar peserta didik dapat secara aktif mengembangkan potensi dirinya untuk memiliki kekuatan spiritual keagamaan, pengendalian diri, kepribadian, akhlak mulia, kecerdasan,serta ketrampilan yang diperlukannya, masyarakat, bangsa dan negara. Selanjutnya dalam pasal 3 dijelaskan tujuan pendidikan nasional potensi peserta didik agar menjadi manusia yang bertaqwa, beriman kepada Tuhan Yang Maha Esa, sehat, memiliki ahklak mulia, berilmu, mandiri, kreatif, cakap, dan demokratis serta bertanggung jawab.

Pada hakekatnya pendidikan menurut Tilaar (2002:435) adalah memanusiakan manusia, yaitu dalam proses menempuh pendidikan adalah proses pembelajaran yang membentuk manusia yang lebih manusia atau dengan kata lain membetuk sumber daya manusia yang berkualitas. Pendapat Tilaar sejalan dengan semboyan Sulawesi Utara yang dikemukana oleh Dr, Sam Ratulangi dalam Bahasa Minahasa"Si Tou Timou Tumou Tou" yang artinya manusia hidup untuk menghidupi sesama manusia. Jika dihubungkan dalam dunia pendidikan guru sebagai sumber daya manusia pada organisasis sekolah bertugas untuk menciptakan sumber daya manusia baru yang berkualitas.

Seperti dijelaskan sebelumnya, secara mikro sumber daya manusia adalah salah satu komponen penting dalam mencapai tujuan suatu organisasi atau lembaga dan secara makro sumber daya manusia adalah penentu keberhasilahan kemajuan bangsa. Oleh sebab itu agar fungsinya secara mikro dan makro dapat bejalan dengan benar maka diperlukan tatanan manajemen dalam pemberdayaan dan pembentukan sumber daya manusia tersebut.

Manajemen sumber daya manusia merupakan suatu hal yang menjadi focus dari manajemen yang bertugas mengaturnya sehingga dapat membantu organisasi atau lembaga mencapai tujuannya. Rivai menjelaskan (2009:1) Manajemen sumber daya manusia merupakan rangkaian aktivitas dan strategis serta proses yang didesain untuk menunjang tujuan organisasi atau lembaga dengan mengintegrasikan kebutuhan organisasi atau lembaga dan individu sumber daya manusianya.

Selanjutnya Hasibuan (2013:10) menjelaskan bahwa manajemen sumber daya manusia adalah ilmu dan seni mengatur peranan dan hubungan tenaga kerja sehingga dapat bekerja seefektif dan seefisien mungkin dalam membantu terwujudnya tujuan perusahaan, karyawaan, dan masyarakat. 
Sementara Mangkunegara (2013:2) menguraikan manajemen sumber daya manusia sebagai suatu pendayagunaan dan pengelolaan sumber daya yang ada pada individu. Penadayagunaan dan pengelolaan tersebut dikembangkan seoptimal mungkin didalam dunia kerja dalam usaha mnecapai tujuan organisasi dan lembaga serta pengembangan sumber daya manusia itu sendiri.

Berdasarkan pendapat-pendapat yang diuraikan diatas maka penulis menarik kesimpulan bahwa manajemen sumber daya manusia merupakan suatu ilmu dan seni dalam suatu pengelolaan sumber daya manusia secara efisien dan efektif untuk mewujudkan tujuan organisasi atau lembaga.

Pendekatan dalam manajemen sumber daya manusia terdiri dari 3 macam yaitu pendekatan mekanis, pendekatan paternalis, dan pendekatan sistem sosial.

Pendekatan mekanis memandang sumber daya manusia sebagai modal atau faktor produksi, dimana pada pendekatan ini manajer menekan pekerja lewat pemberian upah yang minim namun mengharapkan produktifitas yang tinggi sehingga biaya produksi menjadi rendah dan keuntungan organisasi menjadi tinggi. Dalam dunia pendidikan pendekatan ini dicontohkan dengan upah dari para guru atau tenaga kependidikan honorer. Mereka dibayar murah namun dituntut untuk menbuat para generasi muda sebagai calon sumber daya manusia menjadi menguasai ilmu pengetahuan, kreatif dan mandiri. Hal ini lah yang menjadi akar permasalah kinerja guru yang tidak maksimal sehingga para sumber daya manusia yang diciptakan mempunyai kualitas yang rendah. Data BPS Sulut menunjukan bahwa jumlah guru pada tahun 2014/2015 4.363 guru termasuk didalamnya guru honorer pada jenjang pendidikan menengah.

Pendekatan yang kedua yaitu pendekatan paternalis. Pendekatan ini dilakukan oleh manjemen untuk mengayomi tenaga kerja atau sumber daya manusia yang ada dalam organisasi. Pendekatan ini dilakukan dengan mengahargai pendapat tenaga kerja, atau dengan memberikan kemudahan bagi para sumber daya manusia seperti memberikan pinjaman atau pembelian kebutuhan pribadi secara kredit. Namun dalam dunia pendidikan khususnya bagi para guru honorer sering pendekatan ini tidak dilakukan karena yang terjadi adalah tenaga honorer harus menunggu berbulan-bulan untuk menrima hak yaitu gaji. Kenyataan ini membuat para guru honorer tidak memberikan kinerja yang maksimal jkarena harus berusaha juga untuk memenuhi segala kepentingan pribadinya.

Pendekatan yang ketiga, yaitu pendekatan system, dalam pendekatan ini organisasi sekolah harus memperhatikan lingkungan luar sekolah yaitu terdapat unsur orang tua, pemerintah dan pemerhati pendidikan serta pengguna lulusan yang tergabung dalam stake holder. Pendekatan ini dimaksudkan untuk membangun kualitas kinerja para sumber daya manusia dalam hal ini guru di sekolah. para manajer perlu menganalisis kebutuhan masyarakat, strandar output yang dibutuhkan, sehingga benarbenar dalam upaya pembelajaran disekolah menghasilkan lulusan yang siap pakai bukan menghasilkan penganguran berdasi.

Tahapan dari manajemen sumber daya manusia diantaranya rekuitment, maintenance, dan pengembangan atau development. Proses recruitment adalah tahapan yang berfungsi menyediakan sumber daya manusia yang berkualitas dan nantinya akan berfungsi untuk mengisi lowong dalam organisasi. Setelah proses tahapan rekuitmen manajer diperhadapkan dengan tahapan pemeliharaan sumber daya manusia. Dalam proses ini pendekatan paternalis merupakan suatu pendekatan yang menentukan, selain itupula pada tahapan proses pemeliharaan ini para manjer perlu meberlakukan panismen dan reward bagi para sumber daya manusia agar dapat memotivasi mereka untuk bekerja optimal.

Selanjutnya tahapan ketiga pengembangan sumber daya manusia perlu dilakukan untuk tetap menjadikan sumber daya manusia tetap berkualitas dengan 
mengikut sertakan mereka dalam pelatihan atau pendidikan dalam rangka mengikuti perkembangan teknolgi. Dalam dunia pendidikan pengembangan sumber daya manusia harus terus dilakukan agar mereka benar-benar dapat memberikan kinerja yang optimal dalam menciptakan sumber daya manusia berkualitas yang baru.

Seperti halnya tujuan pendidikan menciptakan seorang yang berkualitas dan memiliki karakter serta pandangan yang luas kedepan untuk mencapai cita-cita dan menjadi seorang sumber daya manusia yang dapat menopang kemajuan bangsa, demikianlah peran pendidikan dalam manajemen sumber daya manusia.

Pendidikan memiliki peran dalam tahapan mananjemen sumber daya manusia yaitu dalam tahapan rekuitmen. Dalam tahapan ini pendidikan berperan untuk menyediakan sumber daya manusia yang berkualitas.

Selanjutnya manajemen sumber daya manusia juga berperan dalam dunia pendidikan. Seperti yang tertuang dalam undang-undang nomor 20 tahun 2003 pasal 39, dimana tenaga kependidikan bertugas melaksankan administrasi, pengelolaan, pengembangan, pengawasan dan pelayanan teknis serta pendidik yang merupakan tenaga professional bertugas merencenakan dan melaksankan proses pembelajaran, penilaian, pembimbingan penelitian dan pengabdian untuk menunjang proses pendidikan. Tahapan-tahapan manajemen sumber daya manusia dan pendekatan-pendekatan berperan menentukan keberhasilan pendidikan.

Dalam proses pembelajaran pun yang merupakan bagian dari pendidikan memerlukan sentuhan manajemen sumber daya manusia.

Fungsi manajemen yaitu planning, organization, actuacting serta controlling merupakan tahapan-tahapan penting yang harus ada dalam suatu proses pembelajaran guna mencapai tujuan pembelajaran dan secara tidak langsung mencapai tujuan pendidikan yaitu menciptakan sumber daya manuisa yang berkualitas.

Menerapkan manajemen sumber daya manusia dalam pendidikan meliputi beberapa kegiatan diantaranya adalah kegiatan, penerimaan, orientasi, pemberian kesejahteraan, panis dan reward. Kegiatan perencanaan tenaga pendidik dan kependidikan adalah strategi dan pengembangan serta penyusunan tenaga pendidik dan kependidikan yang komprehensif guna memenuhi kebutuhan organisasi di masa depan. Awal pelaksanaan fungsi manajemen sumber daya manusia adalah perencanaan sumber daya manusia. Meskipun langkah awal terkadang langkah ini tidak diperhatikan dengan benar bahkan sering diabaikan, sehingga terjadi masalah, contohnya ada sekolah yang kelebihan guru dan sekolah lainnya kekurangan guru. Masalah ini menyebabkan masalah kinerja kurang maksimal, disebabkan disekolah yang kelebihan guru sebagian guru tidak mendapatkan hak sertifikasi karena jumlah jam mengajar kurang. Sebaliknya masalah yang timbul disekolah yang kekurangan guru adalah kinerja guru tidak maksimal karena kecapaian mengajar dengan jumlah jam yang tidak standar. Mengatasi hal ini pimpinan sekolah dapat berupaya mengadakan guru honorer namun karena keterbatas sumber dana maka mereka dibayar rendah sebagai contoh Rp 300 ribu / bulan, hal ini juga menyebabkan kinerja guru honorer tidak maksimal karena ketidakpuasan.

Pada kegiatan yang kedua peran manajemen dalam pendidikan yaitu penerimaan. Kegiatana penerimaan ini berfungsi untuk menyeleksi dengan seksama para sumber daya manusia yang melamar sesuai dengan kompetensi yang dibutuhkan, sehinnga pelamar yang diterima merupakan sumber daya manusia yang berkualitas pada bidangnya.

Setelah kegiatan penerimaan dilakukan penempatan sesuai dengan spesifikasi keahlian, dan walaupun mereka adalah ahli dibindangnya perlu diadakan kegiatan orientasi untuk memperkenalkan karakteristik 
pekerjaan, mitra dalam bekerja bahkan lingkungan dan aturan-aturan pekerjaan yang berlaku.

Selanjutnya ketika para pekerja sudah memberikan yang terbaik dirinya, saatnya mereka menerima kesejahteraan atau penghargaan dalam bentuk upah, jaminan kesehatan dan lain-lain. Tujuan pemberian kesejahteraan adalah 1) untuk mneingkatkan ketrtarikan dan kesetiaan pegawai dengan organisasi atau lembaga, 2) memberikan pemenuhan kebutuhan dan ketenangan bagi pegawai dan perusahaan, 3) memotivasi gairah kerja, produktivitas pegawai dan disiplin, 4 menurunkan tingkat absensi, 5)

\section{PENUTUP}

Pada hakekatnya pendidikan adalah "Si Tou Timou Tumou Tou" yang artinya manusia hidup untuk menghidupi sesama manusia. Dalam dunia pendidikan guru sebagai SDM lembaga pendidikan bertugas untuk menciptakan sumber daya manusia baru yang berkualitas. Selanjutnya manajemen SDM dibutuhkan dalam pendidikan baik pada tingkat makro dan ditingkat mikro sehingga tujuan pendidikan tercapai atau pendidikan menciptakan suasana kerja yang nyaman, 6) membantu lancarnya pekerjaan (Hasibuan, 2013:187)

Kegiatan yang tak kalah penting juga dalam manajemen sumber daya manusia dalam pendidikan adalah pemberian panismen dan reward, baik dalam bentuk promosi naik pangkat atau panismen dalam bentuk mutasi, atau pemutusan hubungan kerja. Hal ini perlu diberikan untuk tetap memotivasi para sumber daya manusia untukmemberikan kinerja secara maksimal sehimhha mereka dapat menciptakan sumber daya manusia yang berkualitas.

mampu menciptakan dan mengembangkan potensi peserta didik agar menjadi manusia yang beriman, bertaqwa kepada Tuhan Yang Maha Esa, memiliki akhlak mulia, sehat berilmu, kreatif, cakap, mandiri dan demokratis serta bertanggung jawab dengan kata lain pendidikan mampu menciptakan sumber daya manusia yang berkualitas dan siap pakai.

\section{DAFTAR PUSTAKA}

Hasibuan, Melayu. 2013. Manajemen Sumber Daya Manusia. Cetakan ke-17. Jakarta. Bumi Aksara.

Mangkunegara, A. Prabu. 2013. Manajemen Sumber Daya Manusia. Bandung. Remaja Rosdakarya.

Rivai,Veithzal.2006. Kepemimpinan dan Perilaku Organisasi. Jakarta. PT.Raja Grafindo Persada Tilaar, H. A. R. 2002. Perubahan Sosial dan Pendidikan. Jakarta. PT. Gramedia. Undang-Undang Sitem Pendidikan Nasional Nomor 20 Tahun 2003.

http://sulut.bps.go.id. 